\title{
Facilitering af selvstudiet i problembaseret læring \\ - et læringsdesign for asynkron kommunikation
}

\section{Henriette Lorenzen}

Lektor, Cand. polyt.

Bioanalytikeruddannelsen,

Professionshøjskolen Metropol

\section{Isa Neimann Thomasen}

Lektor, Cand. scient.

Bioanalytikeruddannelsen,

Professionshøjskolen Metropol

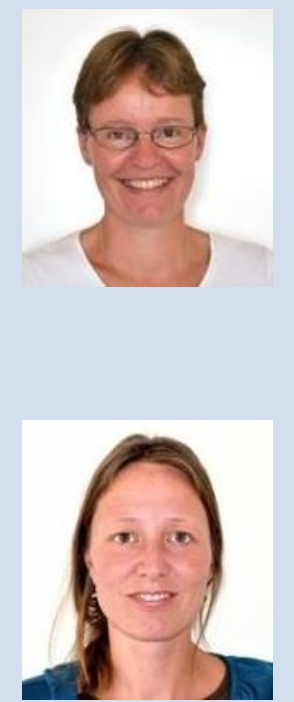




\section{Abstract (dansk)}

Ved Bioanalytikeruddannelsen på Professionshøjskolen Metropol praktiseres problembaseret læring (PBL) ved at føre de studerende gruppevis gennem en struktureret læringsproces, der faciliteres af en tutor og initieres af åbne virkelighedsnære problembeskrivelser. Processen fører til, at gruppen opstiller egne læringsmål, som de studerende i det efterfølgende selvstudie afdækker ved selvstændig indhentning og bearbejdning af viden. Forløbet afsluttes ved en faglig diskussion i gruppen. Alle led i processen er essentielle for de studerendes læring og for, at de pædagogiske hensigter med PBL indfries.

Der har været stor fokus på, hvordan problembeskrivelsen, tutors rolle og gruppedynamik har indflydelse på læringsprocessen i PBL. De studerendes selvstudie har derimod fået mindre opmærksomhed.

Artiklen præsenterer et læringsdesign for, hvordan digital understøttelse kan kvalificere de studerendes selvstudie under hensyntagen til PBL-princippet om selvstyret læring. Konkret arbejder de studerende under selvstudiet i et kollaborativt online dokument, hvor indlæg er styret af læringsmålene, fagligt kvalificeret gennem asynkron kommunikation med medstuderende samt feedback fra tutor.

Artiklen diskuterer med udgangspunkt i data indsamlet fra de studerendes evalueringer og tutorers iagttagelser, dels læringsdesignets betydning for de studerendes arbejde og læring under selvstudiet og dels potentialet ved brug af læringsdesignet som et refleksionsredskab for undervisere.

\section{Abstract (engelsk)}

At the Biomedical Laboratory Science Programme, Metropolitan University College Problem-based learning (PBL) is practiced by guiding groups of student through a structured learning process. This process is facilitated by a tutor and initiated through open-ended and real-world cases. The process leads to the group formulating their own learning objectives. Subsequently the students cover these objectives in their self-study through individual collection and processing of information. The process is finalized in a professional dialogue in the group. All steps in this process are essential both to the learning of the students, and for PBL to succeed as a pedagogical method. 
Typically the main focus has been on how the compilation of the problem, the relationship to the tutor, group dynamics and method design has influenced the learning process in PBL. However, the student's self-study has only been subject to minor attention.

This paper presents a learning design on how digital support can qualify the student's self-study, with due consideration to the PBL principle of selfdirected learning. Concretely the students work in a collaborative online document where posts are guided by the learning objectives, qualified through an asynchronous communication between the students and feedback from the tutor.

Based on tutor observations and data gathered from the students' course evaluations, the paper discusses both the impact on the students work and learning during self-study and also the potentials of using the learning design as a means of reflection for the tutors.

\section{Introduktion}

Bioanalytikeruddannelsen er en mellemlang videregående professionsbacheloruddannelse, der uddanner de studerende til at varetage og kvalitetssikre laboratorieanalyser og patientundersøgelser og dermed til at indgå i det diagnostiske samarbejde på de danske sygehuse.

På Bioanalytikeruddannelsen i København har vi igennem de sidste 15 år anvendt Problem Baseret Læring (PBL) i studiets sidste halvdel med henblik på at lade de studerende indgå aktive og motiverede i læreprocesser, der er tæt koblet til praksissituationer og som samtidig udvikler læringskompetencer, der kan bidrage til livslang læring i en sektor, der er i konstant udvikling.

Vi anvender den såkaldte 7-trins PBL-model (Schmidt, 1983). Ved denne model aktiveres de studerende gruppevis igennem en struktureret proces, der er initieret af en åben problembeskrivelse eller en "trigger" og faciliteret af en tutor. Processen resulterer i, at gruppen identificerer egne læringsbehov og opstiller læringsmål, der formuleres som konkrete og afgrænsede spørgsmål. Læringsmålene fungerer som guides for selvstudiet, der er den del af PBLforløbet, hvor de studerende selvstændigt indhenter og bearbejder den viden, der besvarer gruppens læringsmål. PBL-forløbene, der typisk er af 1-2 ugers varighed er flerfaglige og professionsorienterede med elementer indenfor bl.a. 
biomedicin, kemi, biologi, fysik og statistik. Alle PBL forløb afsluttes med et gruppemøde, hvor læringsmålene afdækkes af de studerende ved faglige diskussioner og fremlæggelser.

Flere peger på, at det kan være vanskeligt at opretholde en god PBL-kultur med et studentercentreret fokus (Moust, Van Berkel \& Schmidt, 2005; Azer, Peterson, Guerrero \& Erdgren, 2012; Barrows, 1986). Azer et al. (2012) beskriver forskellige generelle tendenser, der kommer til udtryk ved dårligt fungerende PBL-forløb. De peger bl.a. på, at de studerende ikke lægger nok kræfter i deres selvstudie og ikke er forberedte ved de afsluttende gruppemøder. Dertil kommer, at de ignorerer deres læringsmål under selvstudiet og i stedet holder fokus på den understøttende undervisning, der kommer til at virke styrende. Disse problemstillinger er genkendelige i vores PBL forløb.

PBL har igennem de sidste 40 år fået stor opmærksomhed såvel i udøvende undervisningspraksis som i den pædagogisk og didaktisk orienterede litteratur (Barrows \& Tamblyn, 1980; Savery \& Duffy, 1995; Pettersen, 1999; Savery \& Duffy, 2006; Schmidt, 1983; Schmidt \& Moust, 2000). Mens fokus særligt har været på problembeskrivelsen (Azer et al. 2012; Barrows, 1986), tutors rolle (Schmidt \& Moust, 2000) og gruppedynamik (Lohman \& Finkelstein, 2000), er de studerendes selvstudie i processen nærmest forbigået. I en studentercentreret undervisningsform som PBL, hvor underviserrollen ændres fra formidler til facilitator ses en tendens til, at selvstudiet ligger udenfor dennes arbejdsfelt. Set i det lys, at de studerendes selvstændige arbejde i PBL udgør et centralt led i læringsprocessen, kan man tale for, at selvstudiet bør have større opmærksomhed, når vi designer og faciliterer læreprocesser.

Facilitering af læring ved anvendelse af teknologi er et stort fokusområde ved Professionshøjskolen Metropol. De studerende ved Bioanalytikeruddannelsen er i dag vant til at håndtere, at deres uddannelse er organiseret digitalt i form af et Learning Management System (LMS) med adgang til eksempelvis lektionsplaner, distribuering af dokumenter og aflevering af opgaver. Teknologien giver dog også mulighed for at supplere det fysiske læringsrum med et virtuelt læringsrum, hvori læring kan understøttes på måder, der ikke opnås i det fysiske læringsrum (Dohn, 2007). Teknologierne anvendes f.eks. med henblik på at facilitere læring af specifik viden eller færdigheder, kommunikation og gruppearbejde eller kritisk vurdering og refleksion 
(Donkers, Verstegen, de Leng, \& de Jong, 2010). Også i PBL-forløb er implementeringen af forskellige teknologier et fokusområde (Verstegen et al., 2016; Ryberg, Glud, Buus \& Georgsen, 2010).

Verstegen et al. (2016), der også pointerer det manglende fokus på de studerendes selvstudie, skriver:
"It is a challenge for instructional designers, teachers and researchers to start thinking about e-learning to support PBL at the curriculum level, to employ different forms of e-learning at different moments in time in order to provide extra scaffolds for PBL group meetings and self-study early on and to help students gradually develop self-directed learning skills up to a level where they can function in PBL groups with less tutor support."
(Verstegen et al. 2016: 27)

Implementeringen af teknologier til facilitering af læring kan imidlertid rykke en studentercentreret undervisningsform i retningen af en mere traditionel og underviserstyret form, hvis teknologierne anvendes uopmærksomt i forhold til det samlede design (Ryberg et al., 2010).

På Bioanalytikeruddannelsen i København har vi en kultur, hvor vi med stort engagement og interesse arbejder med didaktiske virkemidler og pædagogiske hensigter i forhold til vores studerende, og den praksis de skal virke i. Men vi har endnu ingen tradition for decideret at systematisere, visualisere og dele udvikling og justeringer af læringsdesigns. Det forholdsvist nye felt Learning Design er interessant i sammenhæng med, at vi ønsker at videreudvikle og styrke vores didaktiske praksis, således at den beror på systematiske refleksioner og eksplicitte beslutninger. Med udviklingen af et design bliver forløbet eksternaliseret og kan indgå som genstand for videre refleksion, forfinelse og fælles vidensopbygning i underviserkollegiet (Laurillard, 2012).

Målet med denne undersøgelse er at udvikle et konkret læringsdesign med henblik på at facilitere selvstudiet i PBL. Vi har særligt fokus på at tydeliggøre underviserrollen så de pædagogiske hensigter med PBL fortsat varetages.

Vi vil udvikle og afprøve et læringsdesign ved at fokusere på 3 udfordringer, som vi ser i forbindelse med vores PBL-forløb: 
For det første yder de studerende ikke den arbejdsindsats under selvstudiet, som er nødvendig for den enkeltes læring og kvaliteten af den faglige diskussion under det afsluttende gruppemøde. For det andet lader de studerende sig styre af den understøttende undervisning, som ikke nødvendigvis besvarer de studerendes egne konkrete læringsmål. Den tredje udfordring er, at de studerende ikke er eksplicitte og grundige nok i afdækningen af læringsmål under selvstudiet, fordi de ikke har udfordret sig selv nok til at opdage og formulere detaljerede sammenhænge.

Vi stiller derfor dette spørgsmål:

Hvordan understøtter asynkron kommunikation de studerendes arbejde og læringsproces under selvstudiet i PBL, og på hvilken måde kan udarbejdelsen af et læringsdesign bidrage til, at de pædagogiske hensigter med PBL samtidig tilgodeses?

Konkret ønsker vi at undersøge, hvorvidt vi ved at indføre asynkron kommunikation i PBL kan:

- $\emptyset g e$ de studerendes studieintensitet under selvstudiet.

- Få de studerende til i højere grad at anvende læringsmålene som guide for deres læring.

- Støtte de studerendes læring ved at understøtte deres brug af skriftligt fagsprog.

Artiklen giver først en kort præsentation af PBL som læringstilgang og metode med fokus på Bioanalytikeruddannelsens tilgang. Begrebet asynkron kommunikation beskrives som metode til facilitering af læring. Derefter præsenterer vi en case, hvor et læringsdesign er udviklet, afprøvet og evalueret gennem et iterativt udviklingsforløb. Ved brug af kvantitative og kvalitative før- og efterevalueringer, fokusgruppeinterview og underviseriagttagelser har vi undersøgt de studerendes studieintensitet $i$ selvstudiet, deres anvendelse af egne læringsmål som guide for læringsprocessen samt de studerendes vurdering af eget læringsudbytte med brugen af skriftligt fagsprog i asynkron kommunikation. Slutteligt præsenterer vi et læringsdesign, der ekspliciterer underviserens rolle med henblik på at sikre fortsat fokus på studentercentreret undervisning. 


\section{Problembaseret læring}

PBL er en studentercentreret undervisnings- og læringstilgang, der er karakteriseret ved, at virkelighedsnære problemstillinger igangsætter en kontekstuel, kollaborativ og selvstyret læringsproces (Barrows \& Tamblyn, 1980; Barrows, 1985).

PBL er baseret på et konstruktivistisk rationale og på den antagelse, at viden konstrueres af den lærende under aktive tankeprocesser. Ved anvendelse af PBL-metoder forsøger man at imødekomme dette rationale ved at lægge rammer, under hvilke de studerende trænes i at konstruere viden $\mathrm{i}$ modsætning til en mere traditionel vidensoverførsel fra underviseren (Savery \& Duffy, 1995).

I bred forstand kan PBL betragtes som et didaktisk koncept, der er styrende for planlægning, gennemførelse, evaluering og vurdering af undervisning og læring. I en mere smal forstand dækker PBL over forskellige undervisningsmetoder, der bygger på nogle grundregler; at undervisningen er baseret på et problem, og at den er studentercentreret og gruppebaseret (Maudsley, 1999; Pettersen, 1999, s. 39, Schmidt, 1993).

\section{Princippet om selvstyret læring}

Et væsentligt aspekt ved PBL - og en af hensigterne med studentercentreret undervisning - er, at de studerende trænes til at blive selvstyrede lærende, og derved til at kunne indgå i livslang læring i en verden, hvor viden hurtigt forældes. Betegnelsen selvstyret læring (Self Directed Learning, SDL) anvendes imidlertid forskelligt. Schmidt \& Moust (2000) anvender f.eks. betegnelsen SDL om dét, de studerende foretager sig i deres selvstudie og sætter således lighedstegn imellem SDL og selvstudiet. Andre har et bredere perspektiv på SDL. Knowles (1975) skrev:

\footnotetext{
“In its broadest meaning, 'self-directed learning' describes a process by which individuals take the initiative, with our without the assistance of others, in diagnosing their learning needs, formulating learning goals, identify human and material resources for learning, choosing and implement appropriate learning strategies, and evaluating learning outcomes." (Knowles 1975: 18)
} 
SDL kan betegnes som læringsprocesser, hvor de studerende, alene eller assisteret af andre, tager initiativ til at tilrettelægge, overvåge og evaluere deres egen læring. Vi deler denne forståelse af begrebet, idet vi anser hele PBL-forløbet inklusive planlagte og strukturerede gruppemøder som studieelementer, der appellerer til, at de studerende er, eller udvikles til at blive selvstyrede i deres læring.

\title{
Studentercentrering og underviserens rolle
}

Underviserens rolle er af stor betydning for, hvorvidt et læringsmiljø er studentercentreret og dermed også for, om der udvikles selvstyrede lærende. I PBL er underviseren erstattet af en tutor, der i stedet for at formidle skal facilitere læringsprocessen og udfordre de studerendes tænkning hen imod at identificere læringsbehov. En opretholdelse af denne rollefordeling med den studerende som den aktive og tutor som en tilbagetrukket og vejledende part anses som værende væsentlig for, at de studerende tager initiativ til og ansvar for egen læring. Barrows (1986) beskrev, hvordan tutor på én gang skal være tilbagetrukket og give de studerende styringen i læringsprocessen og på samme tid skal sikre, at de indgår struktureret og refleksivt i læringsprocessen:

\begin{abstract}
"If the students are not given the freedom to reason and learn on their own because of an overly directive tutor, or if the students are not guided by the teacher to consider all the steps in the hypotheticodeductive reasoning processes, always to question whether they have learning needs as they work, and to choose and use a variety of resources in their learning, then objectives are compromised..."
\end{abstract}

(Barrows 1986: 485)

Man kan sige, at tutorrollen er at være "usynligt styrende" forstået på den måde, at de studerende oplever at være frie i deres tænkning og undring samtidig med, at de ledes igennem en videnskabelig tankeproces. At være tutor er at udvise en undervisningskompetence, der fremmer selvstyret og aktiv læring, og som derfor er helt central i PBL.

\section{PBL på Bioanalytikeruddannelsen}

På Bioanalytikeruddannelsen er PBL struktureret som 7-trinsmodellen ("7jump", Schmidt, 1983) også kaldet Maastricht modellen (Schmidt \& Moust, 2000). Denne model afspejler videnskabelig tænkning og metode og tager 
bl.a. udgangspunkt i Dewey's beskrivelse fra 1933 af refleksiv tænkning (Dewey, 2009, s. 95-102). PBL-modellen er udviklet på Maastricht Universitet for at imødekomme udfordringer med, at unge studerendes læringskompetencer ikke rakte til, at kunne indgå i mindre instruktive modeller (Schmidt \& Moust, 2000). Vores brug af PBL har således fokus på udvikling af læringskompetencer samt kollaborativ og kontekstuel læring, snarere end udvikling af klinisk ræsonneren og beslutningstagen, som PBL oprindeligt blev designet til.

De studerende introduceres grundigt til PBL og 7-trinsmodellen med fokus på vores intention og metode ved et 3-dages introduktionsforløb. De 7 trin guider gruppen til først at klargøre fakta i problembeskrivelsen, herunder at udrede ukendte termer og sammenhænge (trin 1), for dernæst at definere problemet eller problemstillingerne (trin 2). De studerende bringer deres eksisterende viden om problemet i spil under en brainstorm og prøver heraf at finde forklaringer og sammenhænge (trin 3). Gruppen forholder sig kritisk til disse brudstykker af viden og forklaringer for at afdække, hvad de ved, og hvad de ikke ved. De opstiller på baggrund heraf hypoteser (trin 4) og dernæst deres egne læringsmål (trin 5), der skal afdækkes ved selvstudie (trin 6). 7. og sidste trin er deling af ny viden i gruppen og efterfølgende integration af den opnåede viden i klare, logiske forklaringer af problemstillingerne. 7- trinsmodellen er skitseret i Fig. 1.

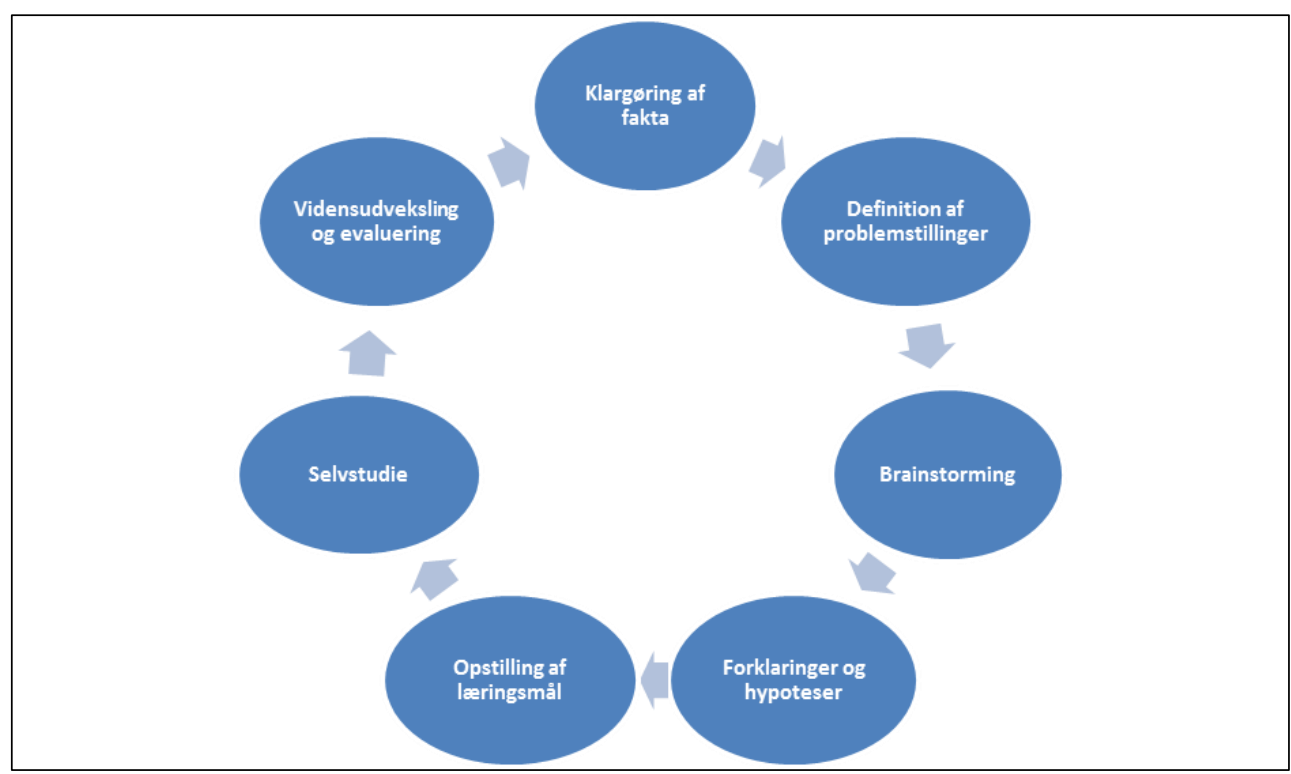

Figur 1. 7-trinsmodellen. Frit efter Schmidt \& Moust (2000). 


\section{PBL gruppemøderne}

Gruppemøder skal henholdsvis lægge op til og afrunde de studerendes problemafdækkende selvstudie. De første 5 trin gennemløbes ved 1. gruppemøde. Praktisk foregår det sådan, at tutor er til stede i den første af to lektioner. De studerende udvælger en sekretær, der på baggrund af problemet og gruppens beslutninger udfylder fem kolonner i et skema, der er projekteret op på tavlen, så alle kan se det. Processen initieres med et problem eller en "trigger" (som f.eks. en åben problembeskrivelse, et resultatudskrift fra laboratoriet eller et foto), der rummer én eller flere problemstillinger, som præsenteres i en virkelighedsnær kontekst. Den kontekstuelle læring er et væsentligt argument for anvendelsen af PBL på Bioanalytikeruddannelsen. De studerende skal opleve relevansen af det, de skal lære, og problemet skal vække deres interesse og motivation til et refleksivt selvstudie. Processen resulterer $i$, at gruppen opstiller læringsmål motiveret af problemet og baseret på den viden, gruppen allerede har om emnet. Der opstilles typisk 10-20 læringsmål, der er formuleret som korte og specifikke spørgsmål. Læringsmålene skal motivere de studerende og guide dem i deres selvstudie. Gruppemødet afsluttes med, at de studerende og tutor drøfter mulig litteratur til selvstudiet samt hvilken understøttende undervisning, der er planlagt i forløbet.

Ved 2. gruppemøde afsluttes PBL forløbet. Her fremlægges den problemafdækkende viden, der er opnået i selvstudiet under afstemning med gruppemedlemmerne. Der evalueres på PBL-forløbet og herunder på selvstudiet; Hvilken litteratur er anvendt? Hvordan er det formuleret i den ene og anden kilde? Er den ene kilde mere relevant end den anden? Det afsluttende gruppemøde har også den funktion, at de studerende hver især bliver konfronteret med deres medstuderendes spørgsmål, hvilket bringer dem til erkendelser af bredde og niveau af egen viden. Tutor faciliterer gruppemødet, giver feedback på gruppens arbejdsproces og på udbyttet af selvstudiet.

\section{Undervisning}

I mellem PBL-opstart og -afslutning og sideløbende med de studerendes selvstudie, tilbydes forelæsninger (FO) og workshops (WS), hvor de arbejder med teoretiske problemstillinger samt laboratorieøvelser $(\varnothing)$, hvor de undersøger teorien i praksis og træner de færdigheder, de skal anvende i professionen (fig. 2). Undervisningen er tænkt som en faglig støtte, der skal 
bidrage til de studerendes afdækning af læringsmålene i selvstudiet. På 3 . studieår er der samlet set tale om 7-14 timer pr. uge afhængigt af PBL-forløb.

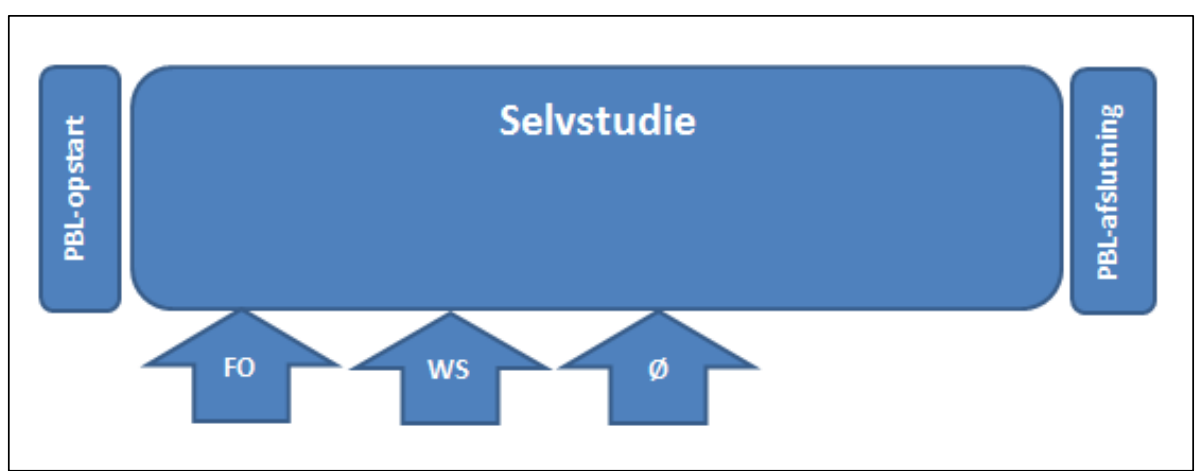

Figur 2. Skitse over et PBL-forløb på Bioanalytikeruddannelsen som viser, at der sideløbende med selvstudiet tilbydes undervisningsaktiviteter til understøttelse af afdækning af læringsmål.

\section{Selvstudiet}

Med selvstudiet menes den del af studiet, der ikke er skemalagt, og hvor de studerende arbejder selvstændigt med at søge og bearbejde informationer til at afdække de læringsmål, de har opstillet i gruppen. De studerende opfordres til at søge og anvende forskellige kilder og læringsressourcer, da de faglige diskussioner i gruppen således bliver både bredere og dybere (Musal et al., 2004).

Selvstudiet udgør på Bioanalytikeruddannelsens 3. år, som casen omhandler, ca. 60 - $70 \%$ af de studerendes studietid. Ved studiestart er de studerende blevet informeret om, at der er tale om et fuldtidsstudium med forventet studietid på godt 40 timer pr. uge, svarende til Danske Professionshøjskolers fælles norm for studieaktivitet (Danske Professionshøjskoler). Denne forventning tydeliggøres ved brug af den såkaldte studieaktivitetsmodel (Danske Professionshøjskoler), der visuelt skitserer hvor stor en del af studiet på de enkelte moduler og semestre, der er planlagt selvstudie.

De studerende har ikke et egentligt pensum, der relaterer til bestemte kilder og kapitler, da det dels vil bryde med det princip, at de selv opstiller deres læringsmål, ligesom det vil forskyde og forstyrre rollefordelingen i PBL fra studentercentrering til undervisercentrering. Derimod er indhold og taksonomisk niveau for alle forløb beskrevet af institutionen med mål for læringsudbyttet. 


\title{
Learning Design
}

Det forholdsvist nye felt Learning Design ses som et forsknings- og udviklingsområde, der både beskæftiger sig med indsamling af empiri til at forstå designprocesser og udvikling af ressourcer, værktøjer og aktiviteter til konkrete læringsdesigns (Conole \& Wills, 2013).

Learning Design er endnu ikke et klart defineret felt, idet forskellige forskere har forskellige perspektiver på området.

Conole \& Wills (2013) ser learning design som en metode, der understøtter undervisere og designere i at træffe kvalificerede beslutninger i designprocessen:

\begin{abstract}
"A methodology for enabling teachers/designers to make more informed decisions in how to go about designing learning activities and interventions, which is pedagogically informed and makes effective use of appropriate resources and technologies." (Conole \& Wills 2013: 25)
\end{abstract}

Koper (2006) ser learning design som et produkt, der beskriver en undervisningspraksis:

\footnotetext{
"A 'learning design' is defined as the description of the teachinglearning process that takes place in a unit of learning (eg, a course, a lesson or any other designed learning event)" (Koper 2006: 1)
}

Dobozy (2011) peger på, at en klar definition af Learning Design er en forudsætning for den videre forskning indenfor feltet og foreslår en klassifikation i 3 niveauer (koncept, proces og produkt), som i et flow fører til udvikling af et konkret læringsdesign.

Et designprodukt kan f.eks. være en præsentation af en konkret læringsaktivitet, et længere forløb bestående af en sekvens af læringsaktiviteter eller en konceptuel model (Dalziel et al., 2016b; Conole \& Wills, 2013, Koper, 2006).

Et centralt princip ved Learning Design er at skabe eksplicitte design, der kan deles og inspirere undervisere til udvikling af egen undervisningspraksis. Intentionen er ikke, at underviserkolleger implementerer et læringsdesign direkte, men at et design eller dele af et design tilpasses til egen kontekst 
gennem en kreativ proces. Underviserrollen flyttes således i retning af at udvikle effektive læringsaktiviteter og dette betegnes at designe for læring (Conole \& Willis, 2013; Laurillard, 2012). Dobozy (2011) peger på, at en struktur for gennemførelse og dokumentation af eksperimenter samt deling af undervisnings- og læringstrategier vil muliggøre udvikling af generiske modeller, som kan anvendes i varierende kontekster med forskellige typer af studerende. Dalziel et al. (2016b) ser udviklingen af et deskriptivt framework til pædagogisk neutral beskrivelse af undervisningspraksis som en forudsætning for deling af design.

Flere forskere ser udnyttelse af teknologiens potentiale i undervisningen som et væsentligt omdrejningspunkt for Learning Design (Dalziel et al., 2016b; Conole \& Wills, 2013; Laurillard, 2012).

I vores tilgang til Learning Design finder vi det interessant, at Laurillard (2012) betegner undervisning som en designvidenskab, der udvikler designprincipper på et fundament af pædagogisk teori. Der er tale om en eksperimenterende tilgang, som bygger på eksisterende viden og som på systematisk vis udvikler, afprøver og dokumenterer et design. Et design eksternaliseres ikke i form af en rapport, men som "a design pattern", der ses som en semistruktureret visuel repræsentation af en løsning på et "problem" i en given "kontekst" (Laurillard, 2012).

Laurillard (2012) ser et potentiale i, at undervisere udfører designforskning som en del af deres professionelle undervisningspraksis, pga. den tætte kontakt til de studerende og særligt med henblik på at eksperimentere med teknologiens rolle i undervisningen. Laurillard (2012) peger på, at forudsætningen for designforskning er til stede, idet undervisere traditionelt arbejder på at forbedre egen praksis og mener, at det vil flytte fokus fra undervisningsplaner i retning af at skabe læring og læringssituationer.

Vi ser således Learning Design som et forskningsfelt, der kan understøtte en eksperimenterende tilgang til udvikling af et konkret læringsdesign set som en sekvens af læringsaktiviteter, der er rammesat af det konkrete læringsdesign. I dette studie har vi både fokus på at udvikle et læringsdesign til at løse en pædagogisk udfordring ved at integrere teknologiens potentiale i en PBLkontekst og på at vurdere Learning Design som refleksionsredskab i designprocessen. 
Vores metodiske tilgang til udviklingen af et læringsdesign er inspireret af Design-Based Research (DBR) (Amiel \& Reeves, 2008; Christensen, Gynther, Petersen, 2012). DBR er kendetegnet ved at have en eksperimenterende tilgang i forhold til en konkret case i en specifik kontekst. Hensigten med DBR er at skabe nye designs til løsning af konkrete og "ægte" problemstillinger i undervisningspraksis og samtidigt at generere ny viden om designprincipper. Antagelsen er, at læreprocesser er afhængige af konteksten, og derfor handler det grundlæggende set om at intervenere i praksis og gennem en iterativ proces at forbedre, afprøve og evaluere et design. Eksperimentet følges op af en generalisering og evaluering af designet med henblik på at sikre robusthed ved implementering herunder også i forhold til at anvende det i andre kontekster (Amiel \& Reeves, 2008; Christensen et al., 2012).

Ambitionen med denne case var at forbedre et eksisterende design i egen praksis gennem et iterativt udviklingsforløb. Der er tale om en mindre undersøgelse, som ikke udvikler et læringsdesign på baggrund af en serie af iterationer og designets robusthed er kun evalueret efter én gennemførelse af undervisningsforløbet.

Metodisk har vi arbejdet med en struktur bestående af fire faser til systematisk udvikling af et læringsdesign: Problemidentifikation, udvikling, afprøvning og dokumentation.

\section{Problemidentifikation}

Første fase udgjorde en kortlægning og identifikation af problemstillingen gennem en analysering af studenterevalueringer, som efterfølgende blev sammenholdt med underviserobservationer.

\section{Udvikling}

I anden fase blev et designforslag til løsning af problemstillingen udviklet. Vi har med udgangspunkt i det eksisterende design og et litteratur-review udviklet et designforslag ved inddragelse af dokumenterede erfaringer fra kollaborative online læringsmiljøer. Designforslaget blev forfinet gennem sparring med deltagende undervisere med henblik på at tilpasse designet til den specifikke kontekst. I udviklingen af designforslaget er vi metodisk inspireret af Conole \& Willis (2013), som fremhæver visualisering af et læringsdesign som en stærk metode til at støtte undervisere i at fokusere på at skabe læringsaktiviteter og se udover fagligt indhold. Visualiseringen ekspliciterer designprocessen, understøtter design-tænkning og sikrer, at 
praksis kan deles. Vi har anvendt metoden som et værktøj til at eksplicitere opmærksomhedspunkter for på et overordnet plan at træffe kvalificerede beslutninger i relation til videreudvikling af undervisningspraksis.

\section{Afprøvning}

I tredje fase blev det nye undervisningsforløb afprøvet og evalueret. Målet med evalueringen var at undersøge om intentionen med designet stemte overens med de studerendes oplevelser. Resultatet af de studerendes evaluering sammenholdt med underviserobservationer var udgangspunktet for en revidering af det første designforslag, som resulterede i et re-design udviklet af de deltagende undervisere. Redesignet er herefter afprøvet og evalueret.

\section{Dokumentation}

Det udviklede læringsdesign blev i fjerde fase dokumenteret visuelt som et struktureret forløb bestående af en sekvens af læringsaktiviteter. Der blev fokuseret på at dokumentere et design med en detaljeringsgrad, som skaber en passende balance mellem præcision og fleksibilitet for på den ene side at understøtte den praktiske tilrettelæggelse af undervisningen og på den anden side at sikre undervisere frihed til at tilpasse designet til konteksten.

\section{Virtuelle læringsrum}

Læringsdesignet er udviklet med udgangspunkt i en gennemgang af litteraturen om virtuelle læringsrum, således at designet bygger på dokumenterede erfaringer.

Verstegen et al. (2016, s. 25) har i et review fundet, at teknologianvendelse i relation til PBL primært benyttes til at understøtte kollaborativ læring. Teknologien anvendes typisk til de studerendes deling af ressourcer og kommunikation mellem fysiske møder. Foruden quizzer er der ikke fundet studier, som beskriver metoder, der understøtter de studerendes forberedelse under selvstudiet forud for PBL-gruppemøder (Verstegen et al., 2016, s. 23-24).

Vi ser et potentiale i at supplere de eksisterende PBL-forløb med et virtuelt læringsrum understøttet af en kollaborativ teknologi til facilitering af de studerendes selvstudie. 
Teknologier kan ikke i sig selv skabe eller støtte relationer og kollaborative studentercentrerede læringsmiljøer (Ryberg et al., 2010), som er centralt ved PBL. Underviserens rolle er således at designe aktiviteter, som udnytter teknologiernes faciliterende potentiale (Laurillard, 2012) og i denne forbindelse at være opmærksomme på principperne for PBL. Verstegen et al. (2016) udtrykker det på følgende måde:
"To genuinely support PBL, e-learning tools and facilities should support or at least not hinder the PBL principles and processes (...): activation of prior knowledge, elaboration, structuring, and restructuring of information, collaborative learning, learning in context, and self-directed learning." (Verstegen et al. 2016: 11)

I det følgende beskrives erfaringer fra kollaborative online læringsmiljøer med særligt fokus på pædagogisk-didaktiske fordele ved asynkron skriftbaseret kommunikation.

Ved asynkron kommunikation bidrager de studerende med individuelle skriftlige indlæg og gennem kommunikation med medstuderende skabes en fælles faglig forståelse. Det faglige indhold kommer således fra flere studerende, som gensidigt er afhængige af hinanden og som i fællesskab konstruerer viden (Sorenson, 2000; Andreasen \& Nielsen, 2013). Den faglige forståelse kvalificeres gennem forhandling med medstuderende. Laurillard (2012) udtrykker det følgende måde:

“...the learner has to construct an idea, explanation, or description. This idea is then available to the others to challenge or modify, and for the originator to defend or redevelop" (Laurillard 2012: 189)

Skriveprocessen, hvor den studerende selvstændigt og med egne ord skal formulere et præcist fagligt indhold, understøtter den studerendes egen faglige forståelse og læringsudbytte (Dysthe \& Engelsen, 2005, s. 277-278). Det at skulle udtrykke faglighed med egne ord tydeliggør for den studerende, hvad der ikke er forstået (Laurillard, 2008), hvilket gør, at skriveprocessen er med til at fremme fordybelse og læsning (Dysthe \& Engelsen, 2005, s. 277278).

Ved asynkron kommunikation fokuseres på ord og fagligt indhold, hvilket af Dohn (2007) beskrives på følgende måde: 


\begin{abstract}
"Koncentrationen om ordene, sammenholdt især med den længere tid, man har til sin rådighed i det asynkrone medie, giver en refleksionsmulighed, som ikke haves i samme grad i ansigt-tilansigt-sammenhængen med dens hurtigere dialog- og undervisningsform."
\end{abstract}

(Dohn 2007: 45)

Det er dog en fordel, hvis de studerende på forhånd kender hinanden gennem tilstedeværelsesundervisning, idet indsigten i hinandens faglige kunnen giver ordene meningsmæssig fylde (Dohn, 2007).

Tutor har en faciliterende rolle i forbindelse med den asynkrone kommunikation og leverer således ikke konkrete faglige informationer (Sorensen, 2010; Stahl, 2006), hvilket understøttes af principperne for Peer Learning i forhold til at understøtte refleksiv læring. Dette beskrives af Boud, Cohen \& Sampson (1999):

"There are increased possibilities for students to engage in reflection and exploration of ideas when the authority of the teacher is not an immediate presence."

(Boud, Cohen \& Sampson 1999: 415)

Det asynkrone læringsmiljø fremhæves således som en metode, der understøtter refleksion og faglig fordybelse (Stahl, 2006).

\title{
Case: Asynkron kommunikation i PBL
}

Udgangspunktet for denne undersøgelse er nydannede PBL-grupper bestående af 4-9 studerende afhængigt af, hvilket laboratoriespeciale de har været i praktik ved. Undersøgelsen omfatter studerende, der går på et modul på 3. studieår, og som derfor er bekendt med PBL-metoden. I alt indgik 33 studerende i undervisningsforløbet, der forløb over 3 PBL-forløb á 2 ugers varighed.

Med henblik på at øge og kvalificere de studerendes studieintensitet under selvstudiet suppleres den eksisterende undervisningsstruktur med læringsaktiviteter i et virtuelt læringsrum, hvor målet er at støtte de studerendes arbejde med egne læringsmål i deres selvstudie. 
I det virtuelle læringsrum struktureres en del af selvstudiet ved at tilrettelægge en skriftlig bearbejdning af PBL-forløbets læringsmål som asynkron kommunikation i et kollaborativt online dokument. Læringsaktiviteten korresponderer således med mål for læringsudbyttet for det pågældende modul, som bl.a. omfatter skriftlig formidling i et præcist skriftsprog med anvendelse af korrekte fagtermer. Målet er, at de studerende udvikler deres professionelle fagsprog gennem formidling af praksis.

Det overordnede princip er, at én studerende formulerer et oplæg til besvarelse af ét læringsmål. En anden studerende formulerer et respons som fagligt kvalificerer oplægget (fig.3). Herefter er det muligt for alle gruppens studerende at bidrage med yderligere respons. En tredje studerende formulerer afslutningsvis en konklusion. De studerende kvalitetssikrer derved oplægget i udarbejdelsen af respons og konklusion. Den asynkrone kommunikation har således forholdsvis få men større indlæg for at undgå at PBL centrale principper som interaktion og diskussion hæmmes pga. manglende overblik, som det er set ved lange trådede asynkrone dialoger (Verstegen et al, 2016, s. 26).

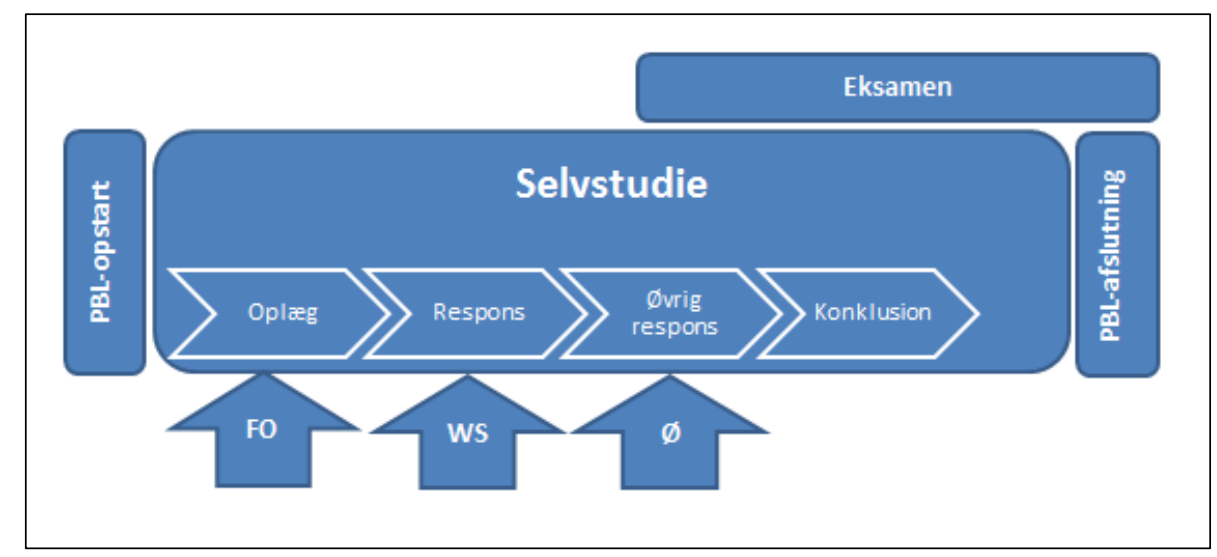

Figur 3. Skitse over PBL-forløb med asynkron kommunikation.

Samtlige læringsmål fordeles blandt de studerende af gruppen og bearbejdes efter samme princip således, at hver studerende samlet set formulerer ét oplæg, ét respons og én konklusion (fig. 4). Udover den skriftlige bearbejdning af de uddelegerede læringsmål er det hensigten, at alle studerende arbejder med alle læringsmål ved vanlige studieteknikker. 


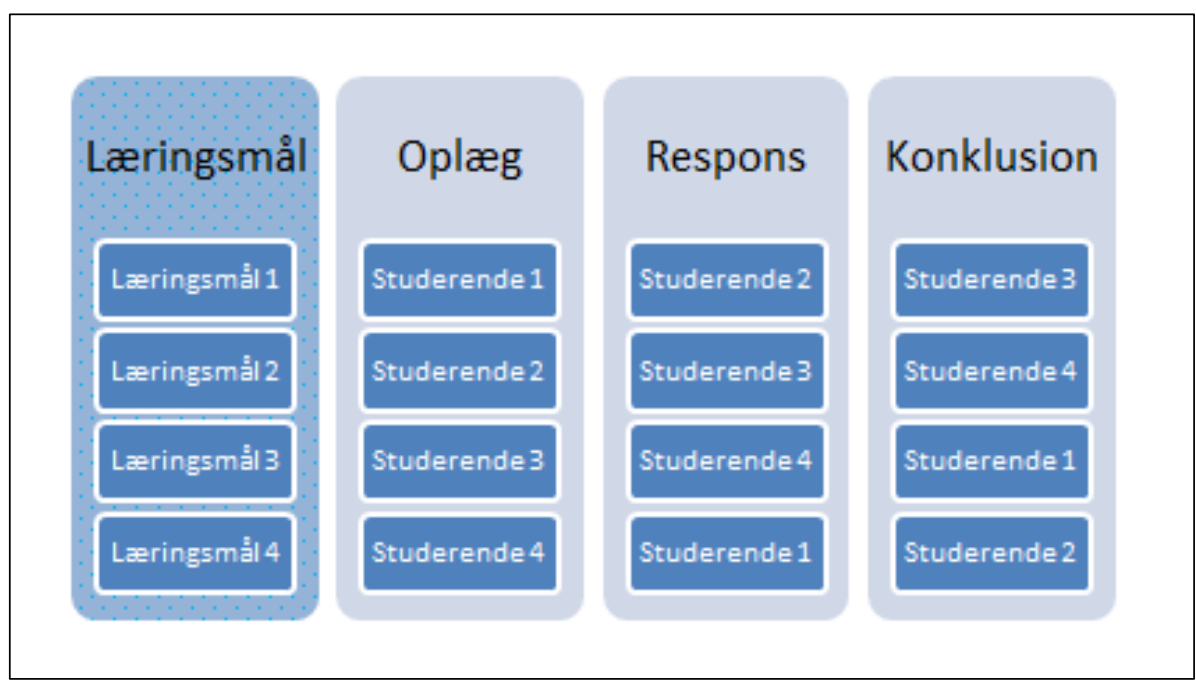

Figur 4. Fordeling af roller i den asynkrone kommunikation.

Den asynkrone kommunikation afvikles i Office 365, som de studerende har til rådighed gennem Metropols Learning Management System. Også her er det vigtigt, at en gruppes aktiviteter struktureres omhyggeligt for at fremme samarbejde og læring (Stahl, 2006; Laurillard, 2012) og derfor er det virtuelle læringsrum i Office 365 på forhånd udformet og fastlagt af tutor. Strukturen er enkel, idet der er oprettet en mappe til hvert PBLforløb med et Word-dokument til hvert læringsmål indeholdende overskrifter til hvert indlæg (fig. 5).

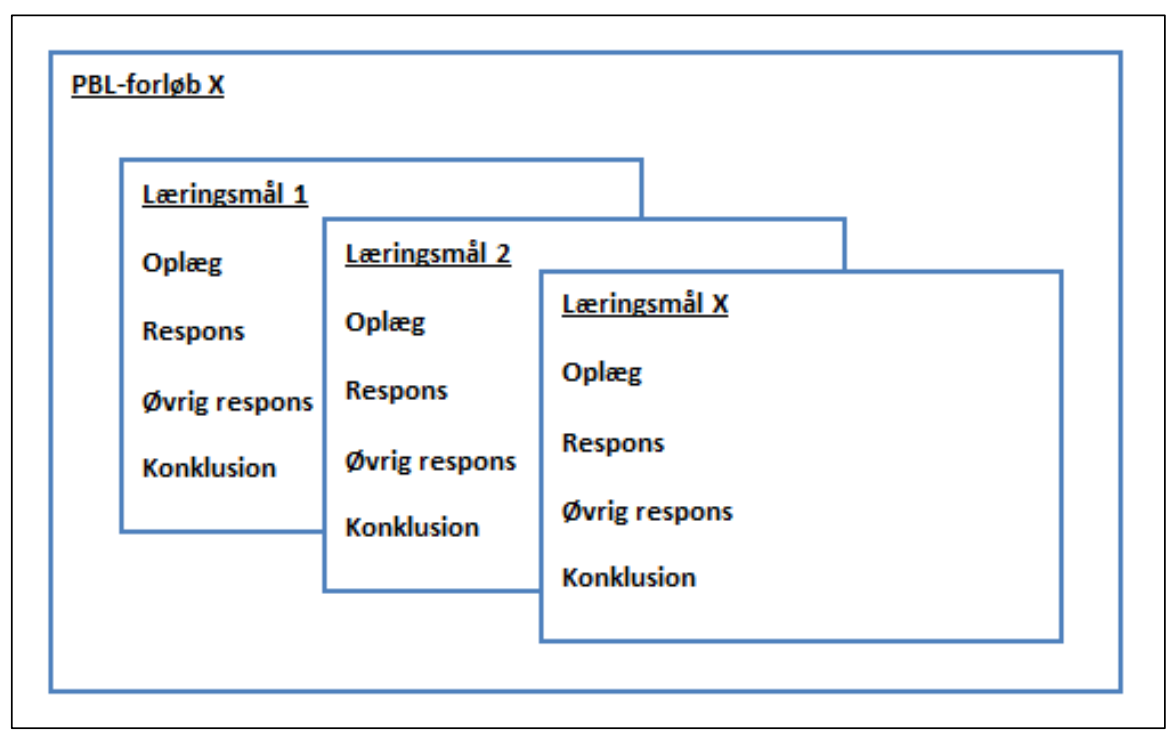

Figur 5. Organisering af dokumenter i det virtuelle læringsrum. 
Rienties et al. (2012) har vist, at en eksplicit struktur både kan virke hæmmende og fremmende for kommunikationen og at dette afhænger af typen af studerende (Verstegen et al., 2016, s. 22). Vi har valgt strukturen, fordi rammerne for selvstudiet ikke må give anledning til forvirring, således at det går ud over det indholdsmæssige aspekt.

Det virtuelle læringsrum er udelukkende åbent for gruppen og tutor, fordi vi mener, at det er vigtigt at kende dem, man deler viden med for at skabe et fællesskab, hvor de studerende også deler det, de ikke har forstået. Et studie af digital understøttelse af PBL viser, at studerende foretrak kollaboration i det fysiske læringsrum og var mindre aktive i det virtuelle læringsrum end forventet (Tambouris et al., 2012). Sammenholdt med at Sorensen (2000) peger på, at asynkron kommunikation kan være svær at få i gang, er der lagt vægt på, at de skriftlige indlæg er obligatoriske og at de skal ligge klar indenfor en valgt deadline. Dette for at sikre aktivitet og at alle studerende har den nødvendige tid til at udarbejde deres indlæg.

Ved introduktionen til modulet præsenteres de studerende for konkrete forventninger til deres indlæg, fordi det øger og kvalificerer de studerendes arbejdsindsats at kende aktiviteternes mål og krav (Laurillard, 2012). Vores forventninger, som de er skrevet til de studerende ses i fig. 6.

\begin{tabular}{|c|c|}
\hline \multirow[t]{5}{*}{ Forventninger } & Minimum $1 / 2$ sides tekst \\
\hline & Billeder og video kan anvendes supplerende til tekst \\
\hline & Indlæg afsluttes med et spørgsmål \\
\hline & Erfaringer fra praktikophold inddrages \\
\hline & Korrekt referencehåndtering \\
\hline
\end{tabular}

Figur 6. Forventninger til de studerendes udformning af indlæg.

De studerende opfordres til at tilføje illustrationer og videoer som supplement til deres tekst og meget gerne illustrationer og oversigter, som de selv har udarbejdet. Illustrationer og videoer kan dog ikke erstatte tekst, da hypotesen 
er, at læringen netop sker ved at skrive. Et indlæg afsluttes med et spørgsmål for på den ene side at understøtte refleksion hos den studerende, som skriver indlægget og på den anden side at hjælpe den næste studerende til at skrive et respons. Det afsluttende spørgsmål understøtter derfor PBL-princippet om kollaborativ læring, idet den asynkrone kommunikation alternativt kan resultere $\mathrm{i}$, at de studerende løser problemstillingerne individuelt.

Kravet om korrekt referencehåndtering er til stede gennem hele uddannelsen, men da de studerende forholdsvist kort tid efter dette modul skal afslutte deres uddannelse med et bachelorprojekt, har vi valgt at have særligt fokus på denne disciplin i dette forløb.

De studerendes refleksioner og diskussion af professionspraksis skal dokumenteres af videnskabelige tekster og forskningsresultater, hvilket afspejler forløbets mål for læringsudbytte. De studerende henter primært viden fra anbefalet litteratur i form af lærebøger, videoer og videnskabelige artikler, men de tilskyndes også til selv at søge supplerende kilder, så et oplæg og et respons belyses af forskellige kilder. Vi opfordrer de studerende til at dokumentere et indlæg vha. flere kilder og lægger vægt på, at de studerende anvender videnskabelige artikler. De studerende forventes derfor at lægge en forholdsvis stor arbejdsindsats i læsningen forud for at skrive et indlæg.

Under introduktionen til modulet informeres de studerende om, at tutor læser indlæggene og som minimum giver generel feedback til den samlede gruppe. Tutors feedback kan være en opfordring til inddragelse af yderligere litteratur og spørgsmål som understøtter refleksion eller hjælper de studerende på rette spor. Vi har en forventning om, at tutors synlighed er med til at motivere og fastholde et højt engagement, således at de studerende leverer en stor arbejdsindsats gennem hele forløbet. Tutors rolle under den asynkrone kommunikation er således faciliterende og adskiller sig derfor ikke fra principperne for PBL.

\section{Eksamen}

Den asynkrone kommunikation er permanent og har derfor et potentiale i relation til at de studerende kan genlæse indholdet og anvende det i en senere sammenhæng (Sorensen, 2000; Stahl, 2006). Denne mulighed for retrospektion udnyttes i relation til eksamen, idet intentionen er, at de 
studerende anvender gruppens asynkrone kommunikation som hjælpemiddel til besvarelse af deres eksamensopgave.

Eksamen afvikles parallelt med PBL-forløbets sidste uge som en 7 dages eksamen, hvor de studerende skal formulere en selvstændig skriftlig opgave på 1,5-2,5 sider. Der er tale om en open-end-eksamen, hvor den studerende selvstændigt skal søge, udvælge og diskutere relevant viden. De studerende har forholdsvis lang tid til besvarelse af opgaven og forventningen er derfor, at de studerende anvender tiden til søgning af yderligere litteratur.

Eksamensformen er valgt på baggrund af princippet om Constructive Alignment - at skabe en klar sammenhæng mellem det pågældende moduls læringsudbytte, læringsaktiviteter og eksamen (Biggs \& Tang, 2007, s. 50-61). Eksamensopgaven tager således udgangspunkt i de studerendes læringsmål, den asynkrone kommunikation og de faglige konklusioner de studerende er nået frem til.

De studerende orienterer sig mod eksamen i forhold til deres læring (Biggs \& Tang, 2007, s. 50-61). Vi vurderer derfor, at eksamensformen tilskynder de studerende til faglig fordybelse under den asynkrone kommunikation og at eksamensformen derfor har positiv indflydelse på de studerendes studieintensitet.

\section{Evaluering}

Modulet er evalueret af 28 ud af 33 studerende ( $85 \%$ ) ved en anonym online spørgeskemaundersøgelse. Som baseline anvendes en tilsvarende evaluering gennemført på et modul et halvt år forinden med de samme studerende, hvor 32 ud af 37 studerende deltog (86 \%).

Besvarelsesprocenten for de to evalueringer vurderes som tilfredsstillende. Den skriftlige evaluering er suppleret med et semistruktureret fokusgruppeinterview med 6 studerende fra 5 forskellige PBL-grupper.

Vi har undersøgt, hvorvidt indførelse af asynkron kommunikation faciliterer de studerendes selvstudie målt på den tid, de bruger, deres anvendelse af egne læringsmål som guide i læringsprocessen samt deres egen vurdering af læringsudbytte ved brug af skriftligt fagsprog.

Samlet set viser evalueringen, at de studerende mener, at de er blevet bedre til at vide hvordan de skal gribe deres selvstudie an. I baseline svarede $34,4 \%$, at 
de var "helt enige" i, at de ved hvordan de skal gøre, når de studerer selv, og denne kategori steg til $66,7 \%$ for det pågældende modul.

\section{Studieintensitet}

En sammenligning af modulets evaluering med baseline viser, at der generelt er sket en forøgelse af studieintensiteten målt ved det timetal de studerende anvender pr. uge.

Generelt er der sket en forskydning, således at hovedparten $(21,4 \%)$ af de studerende anvender 25-30 timer pr. uge. Baseline viste, at hovedparten $(21,9) \%$ af de studerende anvendte 20-25 timer pr. uge. Andelen af studerende som anvender det forventede antal timer pr. uge er også steget, idet $25 \%$ af de studerende svarede, at de anvender mere end 40 timer pr. uge, og denne kategori udgjorde 6,3 \% for baseline. Alt i alt ser vi altså en øget studieintensitet målt på de timer, de studerende angiver at bruge. Tallene skal dog tolkes varsomt grundet det lave antal studerende, der indgår i undersøgelsen og fordi undersøgelsen kun måler på én gennemførelse af undervisningsforløbet.

Hvorvidt den øgede studieintensitet rent faktisk skyldes indførelse af den asynkrone kommunikation eller om den er et udtryk for, at der blev arbejdet intenst med andet i selvstudiet, er også svært at vurdere. Ved fokusgruppeinterviewet spurgte vi de studerende, om de brugte mere tid på afdækning af læringsmålene, når der skulle udarbejdes et indlæg, respons og en konklusion. De studerende svarer meget forskelligt, idet nogen brugte mindre tid og andre mere tid. Årsagen til at nogen studerende anvendte mindre tid skyldes tilsyneladende, at de studerende har uddelegeret læringsmålene og dermed udelukkende har fokuseret på ét eller ganske få læringsmål:

\section{"Jeg har brugt mindre tid på læringsmål, da der kun er ét læringsmål at fokusere på ad gangen"}

Flere studerende fremhæver eksamensformen som årsagen til, at de anvender mindre tid på læringsmålene, hvilket kommer til udtryk i følgende udsagn:

"Jeg synes PBL [Asynkron kommunikation] fungerede rigtigt godt

- det kunne have været godt og jeg kunne have brugt mere tid, hvis ikke eksamen havde ligget midt i forløbet" 
Andre studerende svarer, at de bruger mere tid på arbejdet med læringsmålene. Af årsager til dette blev nævnt, at der var tale om individuelt arbejde, der blev vurderet af andre, samt at det tager tid at finde figurer og at formulere sig skriftligt:

\section{"Hvis jeg skal præsentere noget for en gruppe... hvis jeg skal ud og fremlægge det. Om det er et skriftligt produkt eller en fremlæggelse. Så lægger jeg mere energi i det"}

Fokusgruppeinterviewet viser, at de studerende arbejder mere intenst, når de skal levere et individuelt produkt, som deres medstuderende er afhængige af:

\section{"Da jeg sad med mit emne [Læringsmål] - sad jeg med noget jeg ikke lige forstod. Jeg havde måske droppet det, hvis ikke andre skulle se det"}

Effekten er dog meget afhængig af de øvrige gruppemedlemmers arbejdsindsats, hvilket kommer til udtryk i følgende studenterudsagn:

"Hvis de andre laver noget, laver jeg også noget"

Generelt set anvender flere studerende flere timer på studiet og en væsentlig årsag er den asynkrone kommunikations synlighed, som tilskynder de studerende til at præstere. Eksamensformen gjorde dog, at ikke alle studerende anvendte mere tid på læringsmålene. Vi havde en forventning om, at eksamensformen ville tilskynde til faglig fordybelse og dermed øget studieintensitet under den asynkrone kommunikation, fordi det faglige indhold ville kunne anvendes som hjælpemiddel ved eksamen. Det blev dog tydeligt, at en eksamen som afvikles delvist parallelt med undervisningen, betyder, at de studerende fokuserer på eksamensopgaven og nedtoner deres arbejdsindsats i den asynkrone kommunikation for at målrette deres læsning mod besvarelse af eksamensopgaven.

\section{Læringsmål som guide i læringsprocessen}

92,9 \% svarer, at de anvender deres læringsmål "meget" eller "noget" som guide i læringsprocessen. For baseline udgjorde denne kategori 87,5 \% og samlet set er der derfor sket en lille fremgang i antallet af studerende, som anvender læringsmålene. Andelen af studerende som anvender 
læringsmålene "meget", var dog større i baseline (46,9 \%) end på det pågældende modul (38,9\%).

Under fokusgruppeinterviewet gav flere studerende udtryk for, at de på tidligere moduler ikke har fordybet sig tilstrækkeligt i arbejdet med læringsmålene, fordi der ikke blev responderet på deres bidrag. Kravet om respons i den asynkrone kommunikation betød, at de studerende fordybede sig mere:

"Vi sprang over hvor gærdet var lavest [før]. Det var ingen der skulle sætte respons på det vi sagde......man uddybede ikke så meget før"

De studerende gav udtryk for, at de gennem fordybelse anvender læringsmålene som guide i deres læringsproces. Som tidligere nævnt fremgik det dog også tydeligt, at flere af de studerende udelukkende fokuserede på det læringsmål, de selv stod for at skrive et indlæg til. En sådan tilgang til den asynkrone kommunikation vil hverken resultere i øget studieintensitet eller understøtte PBL som læringsform.

\section{Læringsudbytte ved brug af skriftligt fagsprog}

$96,3 \%$ af de studerende svarer, at de er "helt eller delvist enige" i, at arbejde med det skriftlige fagsprog er godt for deres læring. Sammenlignet med baseline, som udgjorde 90,6 \%, ses en lille stigning. Andelen af studerende som svarer, at de er "helt enige" i at arbejdet med det skriftlige fagsprog er godt for deres læring, er steget fra 53,1 \% til 66,7 \%.

Det er vanskeligt at måle læring og faglig indsigt, og det vi får svar på er de studerendes opfattelse af, hvorvidt skriftlighed understøtter læring. Det kan tyde på, at de studerendes skriftlige arbejde har gjort dem mere bevidste om, at det at skulle formulere noget fagligt på skrift, er godt for læringsprocessen. Ved fokusgruppeinterviewet udtrykte to studerende:

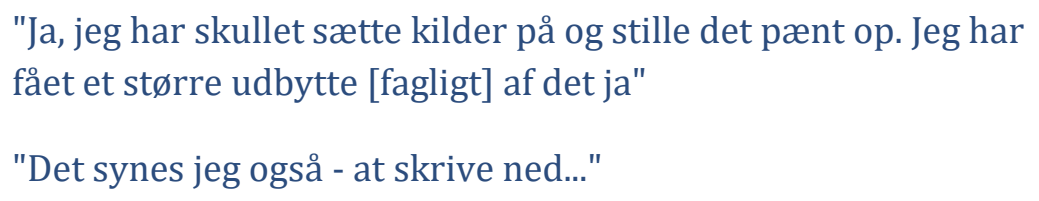

De studerende er således bevidste om, at skriftlighed understøtter deres læring, og det tyder på, at den asynkrone kommunikation har skærpet deres opmærksomhed på dette. 
Ved fokusgruppeinterviewet har vi spurgt til, om de studerende kunne komme med konkrete eksempler på, hvad den skriftlige bearbejdning har betydet for deres faglige indsigt. De svarer, at de søger mere litteratur, fordyber sig mere og arbejder med det skriftlige fagsprog, hvis de har fundet det vanskeligt at besvare et læringsmål.

Tutorerne iagttog, at flere studerende, mødte mere og bedre forberedte til PBL-afslutningen, hvilket viser os, at de studerende har udfordret sig selv under selvstudiet, og at den asynkrone kommunikation har bidraget til dette. De studerende mødte dog ved det afsluttende gruppemøde med en forventning om, at de havde nået deres læringsmål, hvilket stillede krav til tutor i forhold til at facilitere en diskussion, hvor de studerende i fællesskab søger en endnu dybere faglig forståelse.

\section{Re-design}

På baggrund af de studerendes evaluering er forløbet efterfølgende blevet justeret. Eksamensformen blev ændret til en 24 timers eksamen, hvor opgavens problemstilling først oplyses efter PBL-forløbet. Den kortere prøvetid betyder, at det vil være vanskeligt for de studerende at søge supplerende litteratur til opgaven. Det er vores forventning, at dette kompenseres af, at de studerende lægger mere energi i den asynkrone kommunikation for at skabe et godt fagligt grundlag til besvarelse af den efterfølgende eksamensopgave.

Det tilpassede undervisningsforløb er på nuværende tidspunkt gennemført én gang for 50 studerende. Modulet er evalueret af 30 studerende (60\%) ved en anonym online spørgeskemaundersøgelse. Besvarelsesprocenten vurderes derfor som tilfredsstillende.

Evalueringen viser, at flere studerende anvender flere timer på studiet, idet 60 $\%$ af de studerende svarer, at de gennemsnitligt anvender 40 timer eller derover pr. uge. En sammenligning af baseline, 1. gennemførelse og 2. gennemførelse (fig. 7) viser således en betydelig stigning i antallet af studerende, som anvender 40 timer pr. uge. 


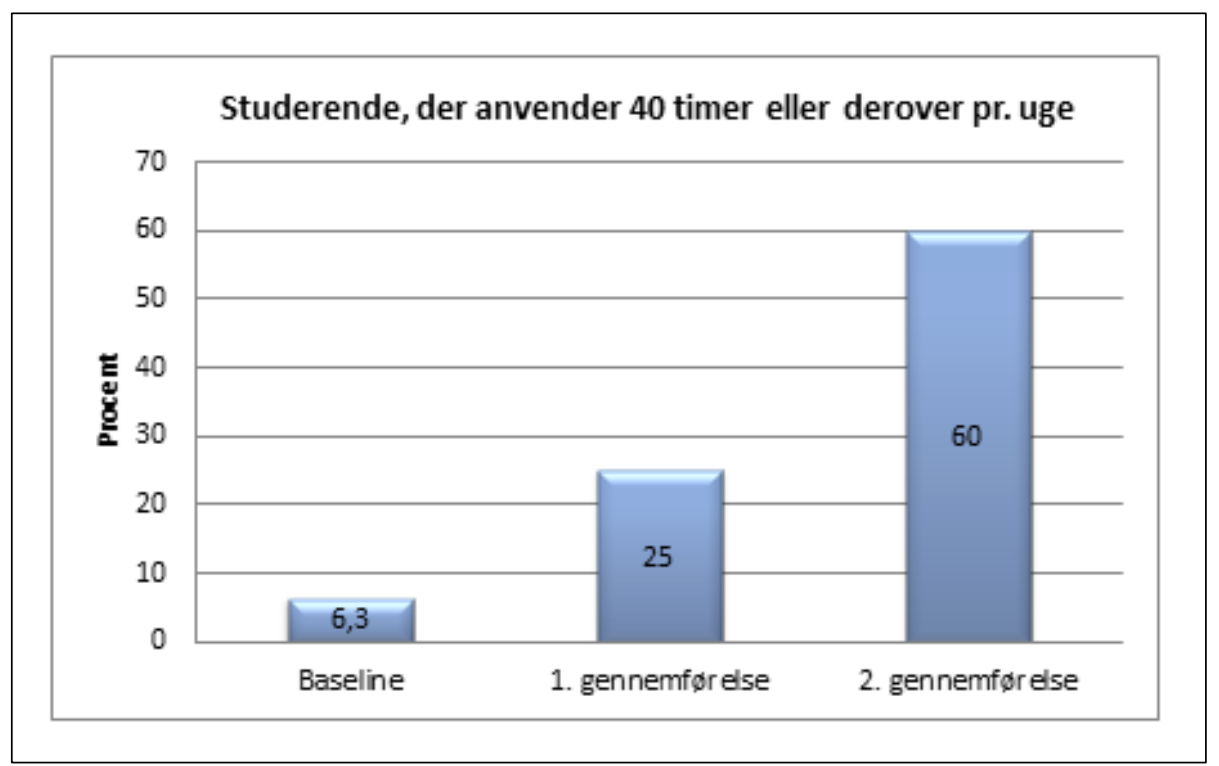

Figur 7. Diagrammet viser hvor mange procent af de studerende der anvender 40 timer eller derover pr. uge i forhold til 1. og 2. gennemførelse af undervisningsforløbet.

Evalueringen viser også, at 73 \% mener, at deres egen forberedelse har bidraget i meget høj grad eller i høj grad til læringsudbyttet. En forholdsvis stor andel af de studerende ser deres selvstudie som en væsentlig faktor for læringsudbyttet, hvilket tyder på, at vi har aktiveret de studerende i den asynkrone kommunikation, og at de studerende kan se udbyttet af indsatsen under selvstudiet.

Supplerende kommentarer i evalueringen viser, at flere studerende fremhæver den asynkrone kommunikation som årsagen til den øgede forberedelse:

\section{"Digital PBL [asynkron kommunikation] hvor alle møder op og bliver nød til at have forberedt sig indenfor noget" \\ "Man har været nød til at forberede sig hjemmefra inden man kom til undervisningen og det har været en god ting"}

Flere studerende fremhæver desuden den asynkrone kommunikation som det, der især har understøttet deres læring og en studerende supplerer med følgende kommentar: 
"Super fedt at prøve at skrive et oplæg/læeringsmål vi selv har lavet til opstart, og give det videre til en anden. Samt at lave respons og oplæg til noget andre har skrevet"

Kommentaren viser, at egne læringsmål anvendes som guide i den studerendes læringsproces.

En studerende fremhæver skriftligheden som understøttende for læringen og ser især kravet om videnskabelighed som væsentligt:

"Super lækkert med en øvelse i kilder og at kunne formulere sig fagligt videnskabeligt"

I en supplerende kommentar giver en studerende udtryk for, at det faglige indhold i den asynkrone kommunikation kunne anvendes som hjælpemiddel til eksamen:

"... sammenhængen mellem PBL og eksamen var rigtig god. Flere af spørgsmålene [læringsmålene] kunne bruges til at besvare dele af eksamensspørgsmålene"

Vi ser det som et udtryk for, at placeringen af eksamen i re-designet har en positiv indflydelse på de studerendes studieintensitet. Kommentaren viser at PBL-gruppen, som denne studerende har været en del af, har anvendt læringsmålene som guide i deres læringsproces. Det faglige indhold er tilsyneladende af en kvalitet, som kan anvendes som hjælpemiddel til eksamen og dette ser vi som et udtryk for gruppens studieindsats.

En analyse af to gruppers ( 5 og 6 studerende) indlæg fra henholdsvis første og anden gennemførelse af undervisningsforløbet viser en forskel i den gennemsnitlige længde af indlæggene, hvilket forstærker formodningen om, at ændringen af eksamensformen øger de studerendes studieintensitet. De to grupper har arbejdet med samme cases og er blevet vejledt af samme tutor. Ved første gennemførelse indeholdt et oplæg/respons gennemsnitligt 220 ord og de studerende anvendte gennemsnitligt 1,5 litteraturkilder. Ved anden gennemførelse indeholdt et oplæg/respons gennemsnitligt 420 ord og de studerende anvendte gennemsnitligt 3,4 litteraturkilder. Målt på antallet af ord og antallet af kilder er der tilsyneladende sket en forøgelse af de studerendes studieintensitet. Vi kan dog ikke udelukke at tutors erfaring i anden gennemførelse og det pågældende hold påvirker resultatet. 
Det leder os frem til at opsummere og visualisere det samlede læringsdesign med fokus på at vise et PBL-forløbs læringsaktiviteters indbyrdes placering over tid, hvilke læringsmæssige ressourcer der stilles til rådighed for de studerende, og hvorledes underviserens rolle ændres gennem forløbet (fig. 8). Undervisningsforløbet veksler mellem et fysisk læringsrum (mørk blå) og et virtuelt læringsrum (lys blå). 


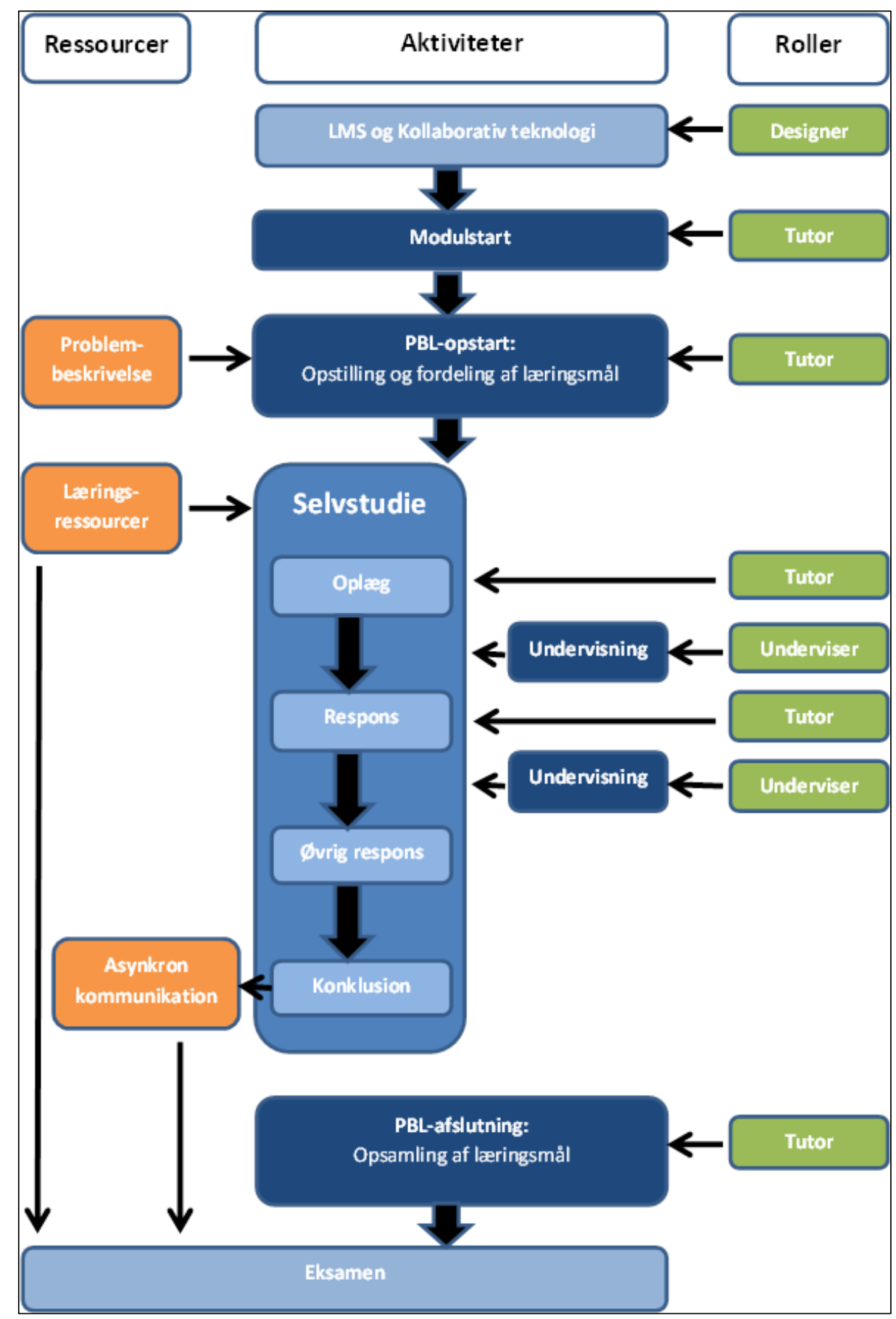

Figur 8 Visualisering af læringsdesign bestående af et fysisk læringsrum (mørk blå) og et virtuelt læringsrum (lys blå). Under selvstudiet arbejdes selvstændigt med læringsmålene understøttet af kommunikation i det virtuelle læringsrum. 
I forbindelse med afviklingen af dette design indgår rollen som designer, underviser og tutor, der kan varetages af samme person med rolleskift undervejs. Designerrollen kan anskues på flere niveauer fra design af et helt PBL-forløb til design af en enkelt aktivitet i forløbet. Der er f.eks. tale om formulering af problembeskrivelser eller "triggere" samt organisering af Learning Management system (LMS) og det virtuelle læringsrum. Rollen ændres til tutor for en PBL-gruppe, hvilket ud over den faciliterende funktion indebærer introduktion til modulets læringsaktiviteter og eksplicitering af krav og forventninger til de studerende. Feedback fra de studerende kan desuden medføre, at tutor vender tilbage til designerrollen og justerer på undervisningsforløbet. Undervisere formidler faglig viden ved forelæsninger og workshops. Læringsdesignet visualiserer dels disse rolleskift og dels graden af interaktion mellem de studerende og undervisere samt tutorer.

\section{Diskussion og konklusioner}

Motivationen for denne undersøgelse var et ønske om at udvikle et læringsdesign, hvori et virtuelt læringsrum faciliterer de studerendes selvstudie under samtidig hensyntagen til de pædagogiske hensigter med PBL og med særligt fokus på underviserrollen. Vi havde et "problem" og en "kontekst" som udgangspunkt for en designproces og dette gav os mulighed for at afprøve visualisering som metode til at eksplicitere udvikling og formidling af et læringsdesign.

De studerende har taget godt imod det virtuelle læringsrum som tiltag til at støtte deres forberedelse under selvstudiet. Vi har gennem det virtuelle læringsrum designet og indskudt en struktur, der udgør en del af deres selvstudie og det er således ikke længere udelukkende op til de studerende selv at finde en form. Vi stiller derfor os selv følgende spørgsmål:

- Går vi imod princippet om selvstyret læring ved at indlægge et obligatorisk element i selvstudiet?

- Erstatter vi selvstudiet med en læringsaktivitet, der fylder de studerendes tid ud med skriftlighed og samarbejde, fremfor at give tid til refleksion og fordybelse på den enkelte studerendes egen præmis?

Vi har gennem det virtuelle læringsrum designet en del af de studerendes selvstudie ved at lægge rammer, hvor indenfor de studerende arbejder 
målrettet, reflekterende og intenst med besvarelse af deres egne læringsmål. Litteratur- og vidensøgning sker (stadig) på de studerendes eget initiativ, ligesom deres refleksioner og bearbejdning af informationer stadig - naturligvis - sker hos de studerende selv. Vi mener derfor, at fastlagte rammer faciliterer og rummer selvstyret læring.

Flere studier peger på at problembeskrivelse eller trigger, gruppedynamik og tutors faciliterende kompetencer er af stor betydning for de studerendes indsats i selvstudiet (Schmidt \& Moust, 2000, Azer, et al. 2012). I denne undersøgelse er omdrejningspunktet facilitering af de studerendes selvstudie ved brug af et virtuelt læringsrum. Det skal ikke ses som et udtryk for, at vi ikke anerkender, at der også er andre løsninger på de udfordringer, vi ser.

Litteraturens manglende fokus på selvstudiet herunder hvordan de studerende konkret griber det an i PBL-regi, kan skyldes en antagelse om, at selvstudiet (som betegnelsen indikerer) skal ske hos den studerende selv uden underviseres eller tutorers indgriben. Man kan argumentere for, at der ikke er tale om et egentligt selvstudie, når aktiviteten er obligatorisk, og når en del af det oprindelige selvstændige studiearbejde erstattes med struktur og samarbejde. Vi ser dog et potentiale i at styrke de studerendes selvstudie ved at definere og strukturere læreprocessen. Dalziel et al. (2016a) udtrykker det på følgende måde:

\footnotetext{
"Even in teaching contexts with a strong focus on the learner, the educator has an important role in structuring the opportunities for learning, and scaffolding the learning process to assist learners to learn."

(Dalziel et al. 2016a: 35)
}

En anden årsag til den manglende opmærksomhed på selvstudiet kan være, at det antages, at de studerende allerede er, eller af sig selv bliver, selvstyrede lærende; de studerende antages at forstå, hvad der forventes af dem i deres selvstudie, hvor meget tid de skal lægge i studiet, hvad de skal fokusere på, hvor de kan finde informationer, og hvordan de bedst og mest effektivt bygger deres viden op på baggrund af disse. Savery (2006) skriver:

\footnotetext{
"The reality is that learners who are new to PBL require significant instructional scaffolding to support the development of problemsolving skills, self-directed learning skills, and
} 
teamwork/collaboration skills to a level of self-sufficiency where the scaffolds can be removed."

(Savery 2006: 15)

Der er muligvis, som Dalziel et al. (2016a) påpeger, sket et skift fra undervisercentreret til studentercentreret læring, som er gået for langt og peger på, at underviseren har en væsentlig rolle i forhold til at tilrettelægge læring.

Det overordnede spørgsmål er dog, om vi er lykkes med at implementere en læringsaktivitet, der tilgodeser vores pædagogiske hensigt. Vi har med dette læringsdesign set, at rammer og struktur kan flytte de studerende ud i succesoplevelser gennem refleksion, fordybelse og oplevelse af anerkendelse i læringssituationer.

At lægge obligatoriske elementer ind i uddannelsen kan nok fremme de studerendes studieintensitet men ikke nødvendigvis deres motivation. Vi ser derfor ikke dét at indlægge obligatoriske læringsaktiviteter som en fremtidig løsning på udfordringer i vores PBL-forløb. Nærværende undersøgelse er afviklet forholdsvist sent i uddannelsen, i forbindelse med at modulets indhold alligevel skulle justeres. Mere hensigtsmæssigt vil det være at afprøve designet på et tidligere modul. Ved at introducere de studerende til det virtuelle læringsrum og asynkron kommunikation som en del af introduktionen til PBL-metoden og herefter overdrage styringen til de studerende på efterfølgende moduler, vurderer vi, at det vil bidrage til, at de studerende gradvist udvikler sig i retning af selv-styrede lærende. Denne progression vil kunne visualiseres i et læringsdesign, hvor undervisning og obligatoriske aktiviteter i selvstudiet gradvist bortfalder.

Evalueringerne viser, at designet er en succes målt på studieintensitet, anvendelse af læringsmål som guide for selvstudiet og inddragelse af skriftligt fagsprog til at fremme læringsudbyttet. Designets væsentligste udfordring var, at ikke alle studerende arbejdede med samtlige læringsmål.

Evalueringen viser endvidere, at de studerendes orientering mod den parallelt løbende eksamen gik ud over arbejdet med deres læringsmål og at en placering af eksamen umiddelbart efter et PBL-forløb i re-designet har en positiv effekt på de studerendes studieintensitet. Vi vurderer, at årsagen til den øgede studieintensitet er en implementering af den asynkrone kommunikation og dens sammenhæng (alignment) med eksamen. Hvorvidt 
den asynkrone kommunikation alene kan bidrage til samme succes, kan vi ikke udtale os om.

Resultatet af undersøgelsen er en præsentation af et læringsdesign, som sigter mod at løse en konkret pædagogisk udfordring ved at anvende en udbredt metode i en ny kontekst. Den asynkrone kommunikation er allerede anerkendt som en metode, der understøtter kollaborativ læring. Vi ser i dette design muligheder i at koble den asynkrone kommunikation med de studerendes individuelle arbejde med egne læringsmål. Ved dette design, hvor teknologien udnyttes til stilladsering og facilitering af selvstudiet i PBL, har underviserens arbejdsfelt ikke blot rykket sig i retning af at designe for læring - det er også rykket ind i de studerendes rum for selvstudie.

PBL praktiseres på mange forskellige måder (Savery, 2006; Barrows, 2003; Barrows 1986) og der ses en tendens til, at PBL-principperne glemmes eller "eroderes" i planlægning og effektivisering af undervisning (Barrows, 2003; Moust et al., 2005; Azer, McLean, Onishi, Tagawa \& Scherpbier, 2013).

Barrows (1986) beskriver f.eks. i sine observationer over udbredelsen af PBL og de forskellige metoder, at mange PBL-programmer er dårligt designede og ikke varetager de grundlæggende principper i PBL. Det er af central betydning, at undervisere og designere for læring er opmærksomme på, hvilken effekt justeringer i design kan have for de pædagogiske hensigter.

Vi ser visualiseringen af et læringsdesign som et refleksionsredskab til at skabe overblik og til at fastholde pædagogiske hensigter under designprocessen. Konkret har udarbejdelsen af et læringsdesign tydeliggjort, hvorledes underviserrollen forskydes i det samlede forløb og skærpet vores opmærksomhed i forhold til balancen mellem studentercentrering og undervisercentrering. Visualiseringen har i designprocessen desuden bidraget til at sikre flow og sammenhæng mellem det fysiske og det virtuelle læringsrum og alignment med eksamen.

Metodisk har vi arbejdet med en designbaseret tilgang (Amiel \& Reeves, 2008; Christensen, Gynther, Petersen, 2012) til udviklingen af læringsdesignet, hvilket har skærpet vores opmærksomhed i forhold til, hvilken betydning de enkelte elementer i designet har for sammenhængen mellem læringsdesignets hensigt og virkning.

Det er vores erfaring, at modellens eksplicitte form kan støtte underviserkollegie og ledelse $i$ at fastholde et fælles udgangspunkt for diskussion og udvikling, således at uddannelsen fremstår som en helhed. 
I en praksis med skiftende undervisningsopgaver ser vi en værdi i forhold til at formidle overblik og pædagogisk idé ved overdragelse af læringsdesign til underviserkolleger. Læringsdesignet kan på samme måde støtte undervisere, som kun har mindre undervisningsopgaver i et længerevarende undervisningsforløb. Vi har lagt vægt på at skabe et læringsdesign med et detaljeniveau, som på den ene side understøtter den enkelte underviser i tilrettelægning af undervisning og på den anden side sikrer frihed til at tilpasse designet til egen kontekst.

Dette læringsdesign er udviklet med udgangspunkt i en konkret udfordring i vores praksis, men vi formoder, at andre uddannelser oplever lignende udfordringer i forhold til deres studerendes selvstændige studiearbejde. Vi ser derfor muligheder for at dele designet eller elementer af designet under forudsætning af, at dette tilpasses pædagogisk hensigt og kultur ved den enkelte uddannelse. Den asynkrone kommunikation er i vores PBL-praksis koblet til de studerendes egne læringsmål, men vi ser et potentiale i at anvende og videreudvikle denne del af designet til en PBL-uafhængig kontekst, således at designet af den asynkrone kommunikation udnyttes mere generelt til facilitering af de studerendes selvstudie.

\section{Referencer}

Amiel, T. \& Reeves, T. C. (2008). Design-Based Research and Educational Technology: Rethinking Technology and the Research Agenda. Educational Technology \& Society, 11 (4), 29-40

Andreasen, L. B. \& Nielsen, J. L. (2013). Dimensions of problembased learning - dialogue and online collaboration in projects. Journal of Problem Based Learning in Higher Education, 1(1), 210-229

Azer, S. A., McLean, M., Onishi, H., Tagawa, M. \& Scherpbier, A. (2013). Cracks in problem-based learning: What is your action plan? Medical Teacher, 35, 806-814

Azer, S. A., Peterson, R., Guerrero, A. P. \& Edgren, G. (2012). Twelve tips for constructing problem-based learning cases. Med Teach 34(5), 361-367

Barrows H. S. (1985). How to Design a Problem-Based Curriculum for the Predinical Years. New York: Springer

Barrows, H. S. (1986). A taxonomy of problem-based learning methods. Medical Education, 20, 481-486 
Barrows, H. S. (2003). Response to "the problem with problem-based medical education: Promises not kept" by R.H. Glew. Biochemistry and Molecular Biology Education, 31(4), 255-256

Barrows, H. S. \& Tamblyn, R. M. (1980). Problem-based learning: An approach to medical Education. New York: Springer

Biggs, J. \& Tang, C. (2007). Teaching for Quality Learning at University. England: Open University Press

Boud, D., Cohen, R. \& Sampson, J. (1999). Peer Learning and Assessment. Assessment \& Evaluation in Higher Education, 24(4), 413-426

Christensen, O., Gynther, K. \& Petersen, T. B. (2012). Design-Based Research - introduktion til en forskningsmetode i udvikling af nye Elæringskoncepter og didaktiske design medieret af digitale teknologier. Læring og Medier, 5 (9)

Conole, G. \& Wills, S. (2013). Representating learning designs - making design explicit and shareable. Educational Media International, 50(1), 24-38

Dalziel, J., Conole, G., Wills, S., Walker, S., Bennett, S., Dobozy, E., Cameron, L., Badilescu-Buga, E. \& Bower, M. (2016a). The Lanarca Declaration on Learning Design - 2013. I J. Dalziel (red.) Learning Design: Conceptualization a framework for teaching and learning online. New York: Routledge

Dalziel, J., Conole, G., Wills, S., Walker, S., Bennett, S., Dobozy, E., Cameron, L., Badilescu-Buga, E. \& Bower, M. (2016b). The Larnarca Declaration on Learning Design. Journal of Interactive Media in Education, 1, 1-24

Danske Professionshøjskoler. Studieaktivitetsmodellen. Retrieved November 11, 2016 from: http://xn--danskeprofessionshjskolerxtc.dk/2474-2/

Dewey, J. (2009) Hvordan vi tænker - en reformulering af forholdet mellem refleksiv tænkning og uddannelsesprocessen. Århus: Klim

Dobozy, E. (2011). Typologies af Learning Design and the introduction af a "LD-Type 2" case example. eLearning Papers, 27, 1-11

Dohn, N. B. (2007). IT-baserede læreprocesser - nogle muligheder og nogle begrænsninger. Universitetspædagogisk Tidsskrift, 3(4), 41-49 
Donkers, J., Verstegen, D., de Leng, B., \& de Jong, N. (2010). E-learning in problem-based learning. I H. van Berkel, A. Scherpbier, H. Hillen, \& C. van der Vleuten (red.), Lessons from problem-based Learning (117-128). Oxford, UK: Oxford University Press

Dysthe, O. \& Engelsen, K. S. (2005). Mapper som pædagogisk redskab. Oslo: Forlaget Klim

Knowles, M. S. (1975). Self-Directed Learning: A guide for learners and teachers. Englewood Cliffs: Prentice Hall/Cambridge

Koper, R. (2006). Current Research in Learning Design. Educational Technology \& Society, 9 (1), 13-22

Laurillard, D. (2008). The pedagogical challenges to collaborative technologies. Computer-Supported Collaborative Learning, 4, 5-20

Laurillard, D. (2012). Teaching as a Design Science: Building Pedagogical Patterns for Learning and Technology. New York: Routledge

Lohman, M.C. \& Finkelstein, M. (2000) Designing groups in problem-based learning to promote problem-solving skill and self-directedness. Instructional Science: An International Journal of the Learning Sciences, 28(4), 291-307

Maudsley, G. (1999). Do we all mean the same thing by 'problem-based learning?' A review of the concepts and a formulation of the groundrules. Academic Medicine, 74(2), 178-185

Moust, J. H. C., Van Berkel, H. J. M. \& Schmidt, H. G. (2005). Signs of erosion: Reflecions on three decades of problem-based learning at Maastricht University. Higher education, 50(4), 665-683

Musal, B., Gursel, Y., Taskiran, H.C., Ozan, S. \& Tuna, A. (2004) Perceptions of first and third year medical students on self-study and reporting processes of problem-based learning. BMC Medical Education 4:16, 1-7

Pettersen, R. C. (1999). Problembaseret læring (1. udg.) Frederikshavn: Dafolo Forlag

Ryberg, T., Glud, L. N., Buus, L. \& Georgsen, M. (2010) Identifying Differences in Understandings of PBL, Theory and Interactional Interdependencies. I L. Dirckinck-Holmfeld, V. Hodgson, C. Jones, M. de Laat, D. McConnell \& T. Ryberg. (red.). Proceedings of the 7th International Conference on Networked Learning 2010 (943-951) 
Savery, J. R., \& Duffy, T. M. (1995). Problem based learning: An instructional model and its constructivist framework. Educational Technology, 35(5), 31-38

Savery, J. R. (2006). Overview of Problem-based Learning: Definitions and Distinctions. Interdisciplinary Journal of Problem-based Learning, 1(1)

Schmidt, H. G. (1983). Problem-based learning: rationale and description. Medical Education 17, 11-16

Schmidt, H. G. (1993). Foundations of problem based learning: some explanatory notes. Medical Education 27, 422-32

Schmidt, H. G. \& Moust, J. H. C. (2000). Factors Affecting Small-Group Tutorial Learning: A Review of Research. I D. H. Evensen \& C. E. Hmelo (red.) Problem-based learning: A research perspective on learning interactions. Marwah, NJ: Lawrence Erlbaum (19-52)

Sorensen, E. K. (2000). Interaktion og læring i virtuelle rum. I S. Heilesen (red.), Universiteter i Udvikling - IKT og Undervisning. København: Samfundslitteratur

Stahl, G. (2006). Communicating with technology. I G. Stahl (red.), Group cognition: Computer support for building collaborative knowledge. Cambridge: MIT Press (273-288)

Tambouris, E., Panopoulou, E., Tarabanis, K., Ryberg, T., Buus, L., Peristeras, V., Lee, D. \& Porwol, L. (2012). Enabling Problem Based Learning through Web 2.0 technologies: PBL 2.0. Educational Technology \& Society. 15(4), 238-251

Verstegen, D. M. L., de Jong, N., van Berlo, J., Camp, A., Könings, K. D., van Merriböer, J. J. G., Donkers, J. (2016). How e-Learning Can Support PBL Groups: A Literature Review. I Bridges, S., Chan, L. K. \& Hmelo-Silver, C. (Red.) Advances in Medical Education: Educational Technologies in Medical and Health Sciences Education. Cham: Springer 